\title{
Polifonia e discurso literário: outras vozes que habitam a voz do narrador na obra Ensaio sobre a Lucidez de José Saramago 1
}

\section{Carina Dartora Zonin*}

Resumo: Neste estudo, propomos evidenciar os discursos que habitam a voz do narrador em Ensaio sobre a Lucidez de José Saramago, segundo os princípios dialógicos de Bakhtin. Observaremos, através da presença de discursos social, religioso e político instaurados pelo narrador, os efeitos de sentido, que, na ficção, tecem uma leitura da realidade.

Palavras-chave: dialogia; polifonia; discurso literário; voz do narrador; efeitos de sentido.
Abstract: In this study we intend to show the speeches that inhabit the narrator's voice in Essay on Lucidity by José Saramago, according to Bakhtin's dialogic principles. Through the presence of social, religious and political speeches established by the narrator we will observe the effects of the senses, which weave a reading of the reality into fiction.

\section{Introdução}

De um modo significativo, o discurso literário apresenta elementos lingüísticos para a produção de efeitos expressivos importantes de serem resgatados na leitura. Na verdade, cada texto literário procura constituir uma singularidade, ser uno no interior do partilhado. Estamos falando aqui de sua construção interdiscursiva que é o lugar de incorporação de um discurso em outro, aonde entrevemos o seu funcionamento polifônico marcado pelas escolhas operadas pelo locutor sobre a língua, enquanto contrato coletivo. Passar para o campo de análise desse discurso requer verificar o percurso de escrita, deslocando-se para o da leitura.

\footnotetext{
${ }^{1}$ Artigo final, defendido em agosto de 2005, para a obtenção do título de Especialista em Estudos Lingüísticos do Texto, através do Instituto de Letras da Universidade Federal do Rio Grande do Sul - UFRGS e que contou com importantes observações das professoras Márcia Ivana de Lima e Silva e Viviane Possamai, que fizeram parte da banca examinadora, além da presença, sempre fundamental, da professora Carmem Luci da Costa Silva que foi luz no meu caminho e que me orientou para a produção deste artigo.

* Carina Dartora Zonin é professora de Língua Portuguesa através do Programa Nacional de Inclusão de Jovens - ProJovem. Destaca-se entre suas publicações: Crônicas Erexinenses: leitura e desleitura na década de 40 (anais); e Nossos Cronistas III. A Voz da Serra, Erechim, n. 346, p. 2, abr. 2001.
} 
Nesta perspectiva, este estudo se propõe a observar os efeitos de sentido produzidos na obra Ensaio sobre a Lucidez de José Saramago, através da análise do funcionamento polifônico da linguagem, constituído na voz do narrador como lugar de habitação de outras vozes.

Como centro desta abordagem, escolhemos o pensamento bakhtiniano, centrando nosso olhar nos textos das obras Questões de literatura e de estética: a teoria do romance (1990), Estética da criação verbal (2000) e Marxismo e filosofia da linguagem (1986) e, ainda em torno dos teóricos de seu Círculo, por sustentar um olhar que busca enxergar a linguagem romanesca como um espaço dialógico de presença e de embate de mais de uma voz. Consideramos que o romance de Saramago representa um universo literário em prosa revelador dos princípios defendidos por Bakhtin que, tendo instaurado o romance como seu campo de observação, percebe a linguagem romanesca de Dostoiévski como uma fonte anunciadora, no século XX, de um pensamento sobre a linguagem, de uma peregrinação que eleva a percepção dos efeitos de sentido a um segundo plano, o do não dito.

Neste percurso reflexivo, procuraremos, através da teoria polifônica, espelhar um olhar sobre a voz do narrador do romance Ensaio sobre a Lucidez, evidenciando, em sua fala, os contornos que trazem a palavra de outrem, pela sua habilidade de colorir e de mascarar o discurso por meio de sua ironia, de sua sátira, de seu humor, de seu ódio, de seu encantamento e de seu desprezo.

Deste modo, buscaremos resposta para a seguinte questão de pesquisa, de caráter abrangente: como se instaura a polifonia na voz do narrador na obra Ensaio sobre a Lucidez, de José Saramago? Além desse questionamento, procuraremos, mais especificamente, responder a outra questão: como se produzem os efeitos de sentido na voz do narrador da obra em estudo para instaurar o outro?

Como um novo elo, povoado de sujeitos na cadeia histórica do pensamento sobre a linguagem, este texto convida a olhar a imagem da palavra enunciada, refletida no outro, "nas vozes que espelham um eu possuído por uma alma alheia" (cf. BAKHTIN, 2003, p.31). Para dar conta deste pensamento, buscaremos fundamentar uma perspectiva dialógica e polifônica para, assim, fazer dialogar os princípios bakhtinianos com a produção literária de Saramago. Em seguida, traremos uma noção de gênero, em sua essência, marcado por um conteúdo temático, por um estilo e por uma construção composicional. 


\section{Ancoragem teórica}

Na concepção bakhtiniana, a consciência individual adquire existência a partir dos signos constituídos no curso das relações e interações de grupos organizados socialmente. Assim, ao teorizar acerca do processo de enunciação, Bakhtin postula a tese do dialogismo lingüístico, concebendo o princípio da intersubjetividade a partir do de alteridade. De fato, o diálogo é concebido em Bakhtin como produto da relação de alteridade entre duas consciências socialmente organizadas e constituídas, já que o auto-reconhecimento do sujeito ocorre pelo reconhecimento do outro. Desse modo, a palavra é território comum entre locutor e interlocutor.

Ao dar conta da enunciação e das interações verbais, o autor estuda as relações entre linguagem, sociedade e história. O exame da enunciação como lugar privilegiado em sua obra aparece através da concepção de enunciado como unidade da comunicação verbal, ligado ao uso efetivo da língua e responsável pela instanciação dos sujeitos e do contexto (o imediato e o sócio-histórico). Por isso, defende ser o enunciado o objeto dos estudos da linguagem. $\mathrm{Na}$ verdade, a sua definição de enunciado parece abarcar as noções de texto como objeto estruturado e como objeto de uma cultura. Tendo em vista a necessidade de operarmos um recorte na vasta obra de Bakhtin, serão aqui tratados três aspectos da reflexão bakhtiniana, a saber: a questão da dialogia, a da polifonia e a dos gêneros do discurso.

\subsection{Dialogia e polifonia na linguagem}

O princípio dialógico permeia todo o pensamento de Bakhtin. O dialogismo é característica essencial da linguagem e elemento constitutivo de todo enunciado, sendo, por isso, condição de seu sentido, já que "a língua penetra na vida através de enunciados concretos que a realizam, e é também através de enunciados concretos que a vida penetra na língua” (BAKHTIN, 1992, p.282).

De fato, o estudo que Bakhtin $(1981 ; 1986 ; 1990 ; 2000)$ faz a respeito da linguagem está vinculado à noção de dialogia, uma vez que a teoria formulada por ele confere à linguagem uma natureza social, por atribuir-lhe uma dimensão dialógica, que dela não pode ser abstraída. Desse modo, toda enunciação, seja procedente de situação oral ou escrita, tem falante e ouvinte ou emissor e receptor, o que lhe concede um caráter de reciprocidade. Sendo assim, a situação social mais imediata (do contexto de troca falante/ouvinte) e o meio social mais amplo determinam inteiramente a estrutura da enunciação, uma vez que não há 
enunciação sem troca, sem diálogo e não há diálogo sem contexto social. Uma dada manifestação verbal é influenciada pelo ponto de vista do outro e pelo ponto de vista da comunidade a que pertence o falante, como coloca Bakhtin (1986, p.121), "a enunciação enquanto tal é um puro produto da interação social, quer se trate de um ato de fala determinado pela situação imediata ou pelo contexto mais amplo que constitui o conjunto das condições de vida de uma determinada comunidade de fala".

Por conceber o dialogismo como um princípio constitutivo da linguagem, o autor estuda a interação verbal locutor/alocutário e o jogo de vozes no interior do discurso (polifonia). No primeiro caso, o da dialogia, argumenta que o outro tem papel fundamental na constituição dos sentidos no discurso do locutor, defendendo que nenhuma palavra é nossa, mas repleta da voz do outro. Essa noção aparece através da idéia de que o falante nunca acha a palavra despovoada das vozes dos "outros", pois nunca a encontramos de forma neutra, sem o ponto de vista de "outros": "a palavra cada falante recebe da voz de outro e repleta da voz de outro" (BAKHTIN, 1981, p.176). No segundo caso, que diz respeito justamente ao jogo existente, no interior do discurso literário, de vozes que, originadas de uma esfera social abrangente, deixam entrever elos que dialogam entre si, que se complementam quando o atravessamento dos discursos quer religioso, quer político, quer histórico, contribui para o entendimento de dizeres que se somam, fortalecendo o discurso, ou, que se contradizem quando o atravessamento desses discursos polemizam-se, denunciando elos que se afastam. Para entrever o funcionamento de tais elos discursivos o autor vale-se do termo polifonia. Essa palavra é usada justamente para caracterizar um tipo de texto em que se deixam entrever muitas vozes, por oposição aos textos monofônicos, que procuram esconder os diálogos que os constituem. A esse respeito, observamos que, na obra de Bakhtin, tanto o texto polifônico quanto o monofônico vinculam-se ao princípio dialógico, enquanto princípio constitutivo da linguagem:

Em outras palavras, o diálogo é condição da linguagem e do discurso, mas há textos polifônicos e monofônicos, segundo as estratégias discursivas acionadas. No primeiro caso, o dos textos polifônicos, as vozes se mostram; no segundo, o dos monofônicos, elas se ocultam sob a aparência de uma única voz. Monofonia e polifonia de um discurso são, dessa forma, efeitos de sentido decorrentes de procedimentos discursivos que se utilizam em textos, por definição, dialógicos. Os textos são dialógicos porque resultam do embate de muitas vozes sociais; podem, no entanto, produzir efeitos de polifonia, quando essas vozes ou algumas delas deixam-se escutar, ou de monofonia, quando o diálogo é mascarado e uma voz, apenas, faz-se ouvir. (BARROS, 2003, p.6)

A presença de polifonia na obra literária é atestada por Bakhtin em seu texto Problemas da Poética de Dostoiévski (1981), em que, a partir dos estudos do romance de Dostoiévski, mostra que, na trama literária, uma consciência pode ser decomposta em várias 
vozes (ter subjacente a ela aspirações e avaliações dos outros). Nesse sentido, como verifica Silva (1996, p.18-19), "Bakhtin observa que a estrutura semântica das enunciações na obra de Dostoiévski é determinada pela antecipação da palavra do outro, formando uma espécie de 'dialogização interna', fato que evidencia a polifonia existente na obra desse autor".

Assim, vemos que, em essência, o pensamento bakhtiniano concebe, de um lado, a dialogia como princípio constitutivo da linguagem e como condição de sentido de todo e qualquer discurso, de outro lado, a polifonia, como um efeito de sentido decorrente de procedimentos discursivos ligados ao discurso literário. Como inerente a toda criação discursiva, observamos o princípio dialógico instanciado na interação entre sujeitos, pelo embate de muitas vozes sociais que se deixam entrever nas diferentes manifestações verbais. Conforme as estratégias discursivas acionadas, a obra literária pode produzir efeitos de sentido de polifonia, em que aparece esse embate de vozes, ou de monofonia, em que as vozes se ocultam atrás de uma única voz.

Trazendo essa reflexão para o nosso campo de interesse, que é o de verificar como se manifesta a multiplicidade de vozes na prosa de Saramago, as noções de dialogia (princípio constitutivo de todo discurso) e de polifonia (efeito de sentido construído no discurso literário, através da instanciação de um embate de vozes), desenvolvidas por Bakhtin, serão de grande valia em nossa análise que pretende dar conta das vozes que habitam a do narrador em Ensaio sobre a Lucidez.

Pela noção de dialogismo, consideramos que o sujeito da criação literária resgata, em suas criações, diferentes olhares sociais oriundos de diferentes esferas (escola, igreja, ciência, etc.). Em outras palavras, um eu potencial (sujeito da criação literária), escuta no discurso o soar das vozes que habitam a linguagem, instaurando efeitos de sentido que mostram um dizer povoado da voz do outro.

A estética da criação literária envolve o encadeamento complexo de enunciados, de linguagens e estilos, que, postos em confronto, em relação com o outro, tecem o diálogo, a escuta da palavra que, em sua natureza, quer sempre ser ouvida. Em outras palavras, a criação literária recupera um já dito (o preexistente) e transfigura-o na representação do enunciado, criado à luz de um estilo e de uma composição, uma visão de mundo, um ponto de vista que concede à tessitura dialógica um caráter plurissignificativo próprio do cruzamento de perspectivas latentes à palavra.

O diálogo com a reflexão de Bakhtin nos permite enxergar a linguagem romanesca impregnada de vozes, já que, ao representar uma dada realidade, o discurso literário é 
revestido de sutilidades e de entonações que instauram as vozes de outros, advindas de diferentes esferas de atividade humana (política, religiosa, educacional, etc.).

Por esse viés enunciativo, elegemos para o nosso estudo uma concepção de discurso como instância dialógica que se faz ouvir por meio de inúmeras vozes que afloram um concerto de incessante produção de sentidos e que dimensionam o fazer literário como um todo que se faz sempre infinito, complexo e inacabado. Assim, a reflexão de Bakhtin será o fio condutor para tecermos considerações a respeito do universo literário de Saramago, focalizando nosso olhar para o romance Ensaio sobre a Lucidez, centro de nossa observação.

\subsection{Os gêneros do discurso}

A tese do dialogismo manifesta-se em torno do tratamento dos gêneros do discurso. Bakhtin interessa-se pelo enunciado, considerado como unidade da comunicação verbal, assim como pelo que denomina gêneros de discurso, tratados como tipos relativamente estáveis de enunciados, porque ligados ao uso efetivo da língua, aos sujeitos e às situações de comunicação, como vemos nas palavras do autor:

O objeto de discurso de um locutor, seja ele qual for, não é objeto do discurso pela primeira vez neste enunciado, e este locutor não é o primeiro a falar dele. O objeto, por assim dizer, já foi falado, controvertido, esclarecido e julgado de diversas maneiras, é o lugar onde se cruzam, se encontram e se separam diferentes pontos de vista, visões de mundo, tendências (BAKHTIN, 1992, p.319).

De fato, os gêneros do discurso refletem, segundo o autor, as formas de representação do mundo e os valores que caracterizam cada grupo social nas diferentes esferas de atividade humana (científicas, legais, literárias, educacionais, políticas, religiosas, etc.). Por isso são instáveis, ilimitados e sócio-históricos. Essa instabilidade pode ser vista em seu tema (conteúdo), em seu estilo (sua forma lingüística) e em sua estrutura composicional (construção), porque refletem as diferentes esferas de comunicação humana próprias a cada grupo e a seu contexto social. Esta tríade (conteúdo temático, estilo e construção composicional) permeia o todo do enunciado e, a cada nova junção, demarca um tipo discursivo e a heterogeneidade dos gêneros.

Já que cada gênero é oriundo de esferas diferentes de atividade humana, Bakhtin reflete acerca do que seja comum entre os gêneros. Para resolver isso, opera uma distinção entre gêneros primários (simples) e secundários (complexos), com o propósito de dar conta do enunciado como constitutivo do gênero. Desse modo, considera gênero secundário como aquele cujos enunciados aparecem em uma circunstância de comunicação cultural complexa 
(ex.: romance) e gênero primário como aquele cujos enunciados constituem o anterior, conservando a sua forma, mas adquirindo um conteúdo no conjunto (ex.: carta inserida no romance). Assim, o que nos interessa nesta reflexão é entender os gêneros em correlação, em caráter de complementaridade, pois o estudo de um gênero secundário (o romance) nutre-se também de discursos primários. A réplica do diálogo cotidiano, por exemplo, que habita ora a voz do narrador ora a dos personagens, insere-se no todo do romance, circunscrevendo um fenômeno da vida literário-artística e, não, simplesmente, da vida cotidiana. Por isso, o estilo é visto em termos de interação entre gêneros.

Como um dos ícones da reflexão bakhtiniana, a estilística confere ao enunciado não só um estilo individual, mas, por estar regida por um determinado gênero do discurso, pode revelar aspectos de um estilo social, marcado pela presença de enunciados que se inscrevem em gêneros peculiares de diferentes esferas de atividade humana, constituídas pelos sujeitos e seus discursos. Como afirma Bakhtin (1992, p.293), "as palavras podem entrar no nosso discurso a partir de enunciações individuais alheias, mantendo em maior ou menor grau os tons e ecos dessas enunciações individuais".

Por natureza, os estilos da língua filiam-se ao gênero e, do mesmo modo, são indissociavelmente vinculados a unidades temáticas determinadas e a unidades composicionais, que versam sobre a estruturação e a conclusão de um todo, bem como ao tipo de relação entre o locutor e os outros parceiros da comunicação verbal/literária e que, respectivamente, institui uma relação com o ouvinte, com o leitor; com o interlocutor, com o discurso do outro.

$\mathrm{Na}$ estética da criação verbal/literária, os gêneros discursivos abarcam uma expressividade típica, que muito diz de seu tema (centro da criação), de seu estilo (entonação expressiva) e de sua composição (recursos lexicais e gramaticais). A palavra, tomada da língua, não incorpora uma significação, um juízo de valor, está a disposição de qualquer locutor e de qualquer juízo de valor que, posto ao lampejo da expressividade, da relação significativa e intencional entre língua e realidade, adquire um colorido expressivo que pode ser totalmente diferente e até mesmo contrário (o triste passa a ser alegre). Conforme Bakhtin (2000, p.312), "o que se ouve soar na palavra é o eco do gênero em sua totalidade".

Neste universo lingüístico e dialógico, a palavra carrega a expressão do outro, que pertence ao plano do tu ou do nós e que impregna de voz o eu do enunciado. Assim sendo, a natureza de uma palavra no enunciado se revela por meio de um invólucro de tradições, que, em sua dimensão sócio-histórica, elucida uma época, um modo de dizer que atualiza, no 
presente, uma tradição, uma crença povoada de sentidos e de vozes, de ecos e lembranças, as quais se filiam a uma dada esfera da comunicação verbal.

$\mathrm{Na}$ trama romanesca, os efeitos de sentido são produzidos pela expressividade própria de determinados recursos, como a ironia, marcando uma intenção do eu em relação ao outro e conferindo um tom dialógico (provocante ou conciliatório), imbuído de criticidade. Isso caracteriza o caráter polêmico e modificador que implica em observar o não dito, o modo como o enunciado se reveste na criação verbal/literária. Observar o discurso do outro, neste percurso, implica ora poder perceber nitidamente o enunciado do outro e o que o acolhe, e ora poder enxergar as vozes alheias nas faces ocultas da criação enunciativa.

Com um óculos estilístico, conforme acepção de Bakhtin, focalizaremos a presença e o confronto de vozes por uma via que não distingue palavras, mas sim, componentes do mundo que, revestidos por um estilo artístico, realçam valores do mundo e, enfim, mostram a relação do homem com o mundo.

Deste modo, com um olhar sobre o texto literário, este estudo pretende mostrar algumas vozes que habitam o discurso do narrador na obra Ensaio sobre a Lucidez de José Saramago e, na perspectiva de Bakhtin, dimensionar uma leitura que distingue as fronteiras existentes entre o eu e o outro. Para tanto, o percurso que seguiremos prescindirá da noção de dialogia, de polifonia e de gêneros de discurso, aspectos essenciais da reflexão de Bakhtin acerca da linguagem, conforme o esboço aqui proposto.

\section{Considerações metodológicas}

\subsection{O objeto sob estudo}

Com uma vasta produção em prosa literária, Saramago escreveu, entre os ensaios, romances como Evangelho segundo Jesus Cristo (1991), de caráter satírico e Memorial do Convento (1982), de caráter histórico. As obras Ensaio sobre a Cegueira (1995) e Ensaio sobre a Lucidez (2004), nosso objeto de análise, assemelham-se no que tange à leitura crítica de uma realidade, em que o escritor potencializa seu estilo de ornamentar palavras, através de um olhar inquieto do mundo, e, artisticamente, transpõe-nos para um universo que joga com os sentidos antagônicos, como cegueira/lucidez.

Deste modo, pensamos em construir um diálogo entre a teoria polifônica de Bakhtin e a linguagem literária de Saramago, já que, para podermos enxergar, claramente, resquícios de 
lucidez nas tangenciais denúncias que se anunciam no romance, necessitamos de um óculos que nos permita ir além do dito.

Como objeto de nossa análise, o romance Ensaio sobre a Lucidez, de José Saramago, encontra pertinência no estudo por se constituir numa reflexão que esperamos não se encerrar em si mesma e trazer aos leitores contribuições significativas que digam que ainda se tem muito a dizer, que mostrem um caminho que, se não for totalmente explorado por nós, possa se perpetuar muito ainda no entrelaçar de vozes, de diálogos inconclusos, que, certamente, emanam da natureza literária da linguagem e do pensamento bakhtiniano sobre este universo.

\subsection{Procedimentos de análise}

Como um elo entre o pensamento bakhtiniano e a obra Ensaio sobre a Lucidez, de José Saramago, elegemos a noção de estilo num sentido peculiar de revestimento do dizer polifônico que o encontra, em essência, na linguagem literária como um alicerce que dimensiona o querer dizer dos enunciados, permeados por uma vertente dialógica. Nesta análise, procuraremos fazer um recorte da obra, elucidando passagens representativas à luz de um ângulo não totalmente lingüístico, mas através de relações de um discurso de outrem que realça vozes de uma esfera social, religiosa e política, e que se encontram impregnadas na voz do narrador.

Em nosso percurso analítico, procuraremos ver, na composição estilística, os efeitos de sentido das vozes sociais que se instituem e povoam o dizer por meio de singularidades que refletem sua natureza e que assumem um dizer sempre afetado, alterado e impregnado pelas relações que o constituem.

Levando em conta as perspectivas dialógica e polifônica, procuraremos instaurar um jeito de olhar para a obra Ensaio sobre a Lucidez de José Saramago, de modo a distinguir os discursos social, religioso e político que habitam a voz do narrador e, deste modo, instituir um diálogo entre o pensamento de Bakhtin e a linguagem saramaguiana. Nesse sentido, concebemos que o sujeito se constitui a partir de um já-dito, que se localiza em diferentes esferas de atividade humana (a sociedade no todo, a religião, a política, a escola, etc.). Por isso, consideramos como discurso social aqueles dizeres oriundos de uma esfera mais geral, ou mais compartilhada pelos sujeitos. Como discurso religioso, aqueles dizeres que, embora sociais, vêm de uma esfera específica - a religião e, como discurso político, aqueles dizeres que se relacionam com a esfera específica de atividade de enfrentamento político-partidário. 
A busca e a evidência de presença desses três discursos na voz do narrador do romance Ensaio sobre a Lucidez de José Saramago será o nosso objetivo no item a seguir.

\section{Uma análise polifônica da obra Ensaio sobre a Lucidez.}

Como evidência do princípio dialógico inerente à linguagem (BAKHTIN, 1981, 1986, 1990, 2000), na obra Ensaio sobre a Lucidez, José Saramago cria efeitos de sentido, mostrando um embate de posições acerca de um sistema que não admite falhas, a democracia. Nesse sentido, apresenta um jogo polifônico na voz do narrador, constituído de vozes que polemizam os discursos oriundos de esferas sociais, religiosas e políticas.

Num universo simbólico e ficcional, Saramago potencializa um romance polifônico, com vozes que se entrecruzam e entabulam palavras que querem e necessitam serem ouvidas, que anunciam uma revolta que toma a cena e invade a vida e o mundo dos personagens. $\mathrm{O}$ voto representa um ato de cidadania e de consciência e ele expeliu uma revolta coletiva refletida no voto em branco, o que também possibilita fazermos uma ponte com o branco que poluiu seu célebre romance publicado em 1995, Ensaio sobre a Cegueira, no qual, em epígrafe, o autor diz: "Se podes olhar, vê. Se podes ver, repara".

Com o mesmo estilo, Saramago polemiza a mesma cor conflitante e apresenta, em forma de denúncia, de uma radicalização não alienada, um dizer que infringe a normalidade e os bons costumes e que, significativamente, colore um Ensaio sobre a Lucidez.

Nesta perspectiva, procuraremos na voz do narrador indícios que, estilisticamente, imprimam este caráter inquietante e conflituoso que sobrevive graças às vozes que dizem muito de crendices e de posturas oriundas das esferas sociais, religiosas e políticas. Tendo em vista a amplitude do romance, selecionamos quatro passagens reveladoras do discurso de cada esfera, a fim de mostrarmos o embate de vozes que habitam a voz do narrador na obra em análise.

\subsection{O discurso social na voz do narrador}

O texto concebido na perspectiva de enunciado (BAKHTIN, 2000) projeta-se, em tons polifônicos, como um porta-voz de uma sociedade reacionária e conflitante graças à pertinência das vozes que tornam o romance saramaguiano um palco de denúncias que tendem a observar o espaço democrático distante das sombras que o rodeiam e instituir uma atmosfera branca capaz de trazer à tona resquícios plenos ora de cegueira ora de lucidez. 
Observamos, no romance, a presença do outro como uma instância definidora do ser humano e das relações que o instituem. No texto de Saramago, o discurso social reflete, através da voz do narrador, a imagem do outro como uma constante a ser perseguida em busca de uma definição do $e u$ e do seu lugar no mundo, na sociedade. Os comportamentos sociais atenuam e polemizam vozes que mostram a natureza do homem aprisionado a um sistema, a uma etiqueta de bons costumes que se instituem na sociedade como que impregnados de aparência, de superficialidades e de ambigüidades, conforme vemos na passagem:

Cumprimentou primeiro os colegas da mesa que actuariam como escrutinadores, depois os delegados dos partidos e seus respectivos suplentes. Teve o cuidado de usar para todos as mesmas palavras, não deixando transparecer na cara nem no tom de voz quaisquer indícios que permitissem perceber as suas próprias inclinações políticas e ideológicas. Um presidente [...] deverá guiar-se em todas as situações pelo mais estrito sentido de independência, ou, por outras palavras, guardar as aparências. (SARAMAGO, 2004, p.9)

Com um olhar atento, o narrador aflora no romance resquícios de um ser social como produto de um contexto social, cultural e político que repercute num comportamento acomodatício, pacífico e "bem adestrado". As ações e os enunciados soam um não dito como a essência do dizer e do agir, incorporando um discurso tecido por muitas vozes que se entrecruzam, se complementam, respondem umas às outras ou polemizam entre si, evidenciando o caráter polifônico da obra de Saramago.

Nesta perspectiva, o estilo entoado pelo narrador-personagem assume, conforme diria Bezerra (2005, p.197), "uma postura de autor participante tanto como condutor do diálogo interno da obra quanto como criador de relações dialógicas, de enunciados plenos que autoexprimem sujeitos reais ou potenciais do discurso". Neste percurso enunciativo, percebemos o discurso e seu concerto incessante de produção de efeitos de sentido reveladores de uma sutilidade que evidencia o seu revestimento irônico e sagaz ao incorporar um mundo que se diz democrático, satirizando as suas glórias e os seus troféus como forma de se auto-revelar: "O agente contentou-se com um movimento afirmativo de cabeça, uma vez que não poderia expressar em voz alta o que pensava, isto é, que é o mérito da idéia que lhe pertencia, é certo que de um modo muito indirecto e por caminho desviado" (SARAMAGO, p.222).

Com efeito, o comportamento social é polemizado pelas vozes e mostram, conforme Barros (2003, p.08), um "confronto de índices de valor contraditório onde se desenvolve a luta de classes". Aqui vemos a problematização da relação entre o homem possuidor da idéia e o homem com poder hierárquico para expressar a idéia, já que somente tem direito à voz aquele que tem poder para tal, o que condiciona o discurso do $e u$ a um mundo de indivíduos 
limitados hierarquicamente. A construção da identidade é omitida em função de um sistema de classes. As vozes tecem um contradiscurso que potencializa o valor da palavra em oposição ao poder de monopólio do saber, desmitificando a origem deste como pertencente a sujeitos privilegiados por um status sócio-econômico e político.

De natureza contraditória, chocam-se os princípios ditos democráticos e um sistema hierárquico que, claramente, nos faz ver as exclusões que se proliferam e se perpetuam nas esferas sociais. As vozes tematizam o sistema democrático contraposto a uma sociedade regida pelo capitalismo como forma preconizada de poder, que traz o apagamento de vozes menos favorecidas.

A voluptuosidade da narrativa deixa transparecer, por meio de comportamentos típicos de um ser social e político, o monopólio do poder e o jogo de interesses que se move com primazia e naturalidade, potencializando uma voz de denúncia, um dizer que, topicalizado numa voz social, instancia uma aliança com o poder numa esfera social que reflete, de caráter abrangente, as veias sociais e políticas de uma sociedade:

Corre por aí a idéia de que a consciência de um comissário de polícias é no geral, por profissão e princípio, bastante acomodatícia, para não dizer resignada com o facto incontroverso, teórica e praticamente comprovado, de que o que tem de ser, tem de ser, e, além disso, tem toda a força de que necessita. (SARAMAGO, p. 251)

Como uma vertente que, em diferentes proporções, incide na voz do narrador, o discurso social potencializa uma leitura do homem e de seu mundo e que, em palavras de Bernardi (2001, p.50) "o homem é colocado em situações extraordinárias que revelam e provocam [...] justamente com a finalidade de experimentar a idéia e o homem da idéia, ou seja, o homem no homem". Como um comportamento refletido, o homem se identifica em face do outro numa formação social; o $e u$, assim, acomoda-se ao regime estabelecido pelo poder hierárquico e, desse modo, as vozes preconizam o homem subordinado à ganância do "ter" e do "poder".

Este encontro do $e u$ em face dos outros joga com os efeitos de sentido e traz à tona uma outra voz que desmistifica o caráter desumano e individualista da sociedade no momento em que o comissário se deixa contagiar pela magia do branco e passa a ver a raiz do sistema político-democrático como uma trama que oscila entre o ser e o não ser, o sentir-se e o não sentir-se humano. O branco deixa de repercutir negativismo e medo e instancia efeitos de sentido que, de imediato, recuperam um sentido socialmente instituído: "Estes felizes sucessos deram uma alma nova ao comissário, como por um passe de magia, da branca, não da negra..." (SARAMAGO, p.312). 
No romance, as nuances de tons conferem à palavra branco efeitos de sentido que jogam, de um lado, com o significado imbricado socialmente, de ser puro, de ser pacífico e que, posto em diálogo com a sociedade governada, repercute numa atitude de lucidez, numa forma de resposta ao mundo da democracia e, de outro lado, em contraposição, com significado, para os governantes, de afronta, de injúria ao sistema democrático, de um estado de loucura por parte da grande maioria dos votantes, soando como um indício de epidemia contagiosa. O sistema dito democrático institui-se como um meio de manipulação e de controle do poder e, para os que o detém em privilégio, o voto em branco insinua a perda de equilíbrio e de monopólio e instaura o medo de uma revolta coletiva posterior.

De um modo representativo, o discurso social ancora-se em pilares que potencializam o embate de vozes e visões que ora jogam com um sistema puramente democrático para os que ainda estão contaminados pela cegueira branca ora atenuam ao sistema as injúrias de ser quase democrático e, em essência, hierárquico e aí se concentra a ressurreição do branco: da pureza e da lucidez imbuídas de um sentimento de denúncia, de descontentamento e de revolta.

\subsection{O discurso religioso na voz do narrador}

Como uma esfera que dialoga com o social, o discurso religioso instancia no romance vozes impregnadas de valores que evidenciam um estilo de polemizar a fé e as crendices populares, jogando efeitos de sentido imbuídos de um culto ao sagrado e ao profano, de uma peregrinação de vozes que, postas em confronto, refletem o quanto tais discursos se impregnam um do outro, se refugiam um no outro e o quanto deixam transparecer uma tentadora relação do homem e do seu mundo.

O apego ao universo simbólico da fé em um Deus superior, em uma voz portadora de um poder espiritual que transcende as limitações do homem, potencializa um discurso que tende a se refugiar no bem, na beleza e na pureza do discurso bíblico da fé, resplandecendo um otimismo histórico, digno de um dizer que funda, no religioso, uma veia política, um discurso que tende à glorificação:

Na verdade, não eram quatro pingos míseros, eram baldes, eram cântaros, eram nilos, iguazús e iangtsés, mas a fé, abençoada seja ela para todo o sempre, além de arredar montanhas do caminho daqueles que do seu poder se beneficiam, é capaz de atrever-se às águas mais torrenciais e sair delas enxutas. (SARAMAGO, 2004, p.10)

Percebemos, na passagem, um culto ao senso comum com a evidência de uma fé preconizada pela religiosidade como uma força absoluta, capaz de vencer todos os obstáculos. 
A figurativização da linguagem impregna às vozes um exagero verbal que insinua o discurso religioso como um meio propício ao fazer crer. Essa voz tende ao convencimento absoluto e, neste emaranhado de intenções, lemos uma forma de cegueira, da branca, não da negra.

O universo social traz à tona uma multiplicidade de discursos que proclamam o apego à crença de que, a contrasenso, percebemos a presença do outro, da voz alheia que insinua, irônica e satiricamente, um embate dialógico que tende a dimensionar. Em palavras de Bezerra (2005, p.194), "o homem em sua verdadeira essência como um outro 'eu' único, infinito e inacabável; não se propõe conhecer-se a si mesmo, conhecer seu próprio eu, propõese conhecer o outro, o 'eu' estranho". Nesta perspectiva, notamos refletida na voz do outro uma injunção subjetiva que diz de uma realidade que se mostra como povoada de sujeitos impregnados de contradições e de interesses individuais que se deixam ver em diálogo com o outro (o eu estranho), que, neste caso, aparece através do discurso religioso: "se é certo que o homem põe, deus é o que dispõe, e têm sido poucas as ocasiões, nefastas quase todas, em que os dois, postos de acordo, dispuseram juntos" (SARAMAGO, p.78-79).

Nesse sentido, vemos que o discurso religioso concede voz a um dizer que impõe igualdade para a relação de diálogo deus/homem. O fato de a palavra Deus ser escrita com a letra inicial em minúscula reflete, em caráter de denúncia, na voz do narrador, um sentimento contrário à fé, à supremacia e à propagação dos valores sagrados, ao cultivo dos ideais de religiosidade e, ao mesmo tempo, de divergência a tudo o que, tradicional e historicamente, convencionamos como princípio de uma cultura assim como o branco passa a ser uma ruptura de um eu coletivo para com os outros que figurativizam poder e superioridade. A relação dialógica deus/homem desmistifica o caráter sublime de um Deus e $\mathrm{O}$ concebe como um homem comum que tem o poder de concessão e que não se faz digna de dizer: ser o homem a imagem e semelhança de Deus.

O uso constante da terceira pessoa instancia, no narrador, o ponto de vista de uma sociedade. Já o instinto de observador que o constitui num eu que, conforme Bakhtin (Lopes 2005, p.79), "olhando para o seu interior, ele o olha nos olhos do outro ou através dos olhos do outro". Deste modo, o discurso tecido pelas vozes do outro confere, claramente, autonomia ao dizer no momento em que o narrador generaliza uma visão conclusiva das ações do homem no mundo:

Sendo o género humano aquilo que sabemos, não poderiam faltar os caprichosos egoístas [...] mas também houve casos de admiráveis renúncias, daquelas que ainda nos permitem pensar que se perseveramos nesses e noutros gestos de meritória abnegação, acabaremos por cumprir com acrescimentos a nossa pequena parte no projecto monumental da criação. (SARAMAGO, p.140-141) 
O jogo polifônico instaura vozes que recuperam discursos bíblicos que versam sobre a criação do mundo. Isto é obtido graças à interferência de um sujeito que abdica do pecado e de tudo que o pode levar a nutrir sentimentos insanos em favor da purificação interior e da construção monumental de um universo que irradia o bem e a beleza, que proclama o papel a que se destina o homem no mundo em busca de uma renovação interior, desmistificando o pecado instituído por Adão e Eva no Paraíso, na origem da criação.

Como um invólucro de tradições, a palavra entoada por vozes sociais preconiza o discurso religioso revestido de um olhar que, segundo os princípios bakhtinianos (2000, p.313), instancia um diálogo com uma dada esfera da vida e da realidade e, ao mesmo tempo, preserva uma entonação típica de uma dada época. O romance saramaguiano enuncia um olhar habitado por uma expressividade que absorve um estigma do comportamento do homem frente à sociedade e aos valores sagrados: "Hoje, tendo deixado de obedecer cegamente às ordens do senhor, os raios só caem onde lhes apetece, e já se tornou evidente e manifesto que não será possível contar com eles para reconduzir ao bom caminho a pecadora cidade do voto em branco" (SARAMAGO, p.208).

$\mathrm{O}$ entrelaçamento de vozes gera efeitos de sentido que dimensionam o todo enunciativo e nos faz ver um mundo que, de subversivo e subordinado às pregações de ordem superior, passou a adquirir voz própria e um dinamismo que não se molda a regras. $\mathrm{O}$ voto em branco representa o rompimento com as tradições de imposição e, com relação a isso, vemos junto à palavra cidade o adjetivo pecadora. De um modo indireto e satírico, as vozes ironizam o poder da religião, através de um discurso que nega esse poder de recondução à cidade pecadora.

Em essência, a voz do narrador evidencia uma proliferação de discursos que cultuam a religiosidade como uma imagem refletida e mediada pelo outro, por um olhar que tende a destacar um culto ao sublime vinculado a um mundo real, a um homem que se deixa imbuir de um mundo que o situa quer em abnegação e respeito quer em contradição e revolta em direção, respectivamente, a um Deus e a uma face de um deus que Saramago evidencia em seu romance e a põe em constante observação e questionamento.

\subsection{O discurso político na voz do narrador}

Com um espírito povoado por uma multiplicidade de vozes, a linguagem romanesca tece fios que, permeados pelo social, resplandecem o religioso e desencadeiam, em vias 
centrais, o político como consagrador de vozes que proliferam uma ideologia partidária e evidenciam a temática central do romance: o sistema democrático.

O entrelaçamento de vozes estigmatiza um perfil consagrado socialmente e que, de um modo representativo, reflete uma postura político-partidária de direita (estilo cauteloso), de esquerda (estilo otimista) e um estilo mediano como forma de elucidar atitudes mais centrais, que unificam características dos pólos de direita e de esquerda e que se constitui num pensamento ponderado. Tais linhas ideológicas se inscrevem no romance como instâncias que dialogam com uma estrutura partidária e fundam um olhar imbuído de uma visão crítica que tende a ironizar as relações que pensam institucionalizar a democracia:

Teria sido preferível adiar as eleições, disse o delegado do partido do meio, p.d.m. [...] O delegado do partido da direita, p.d.d., fez um gesto concordante com a cabeça, mas considerou que a sua contribuição para a conversa deveria revestir a forma de um comentário cauteloso [...] Não chegámos portanto a conhecer o ponto de vista do delegado do p.d.e., porém, avaliando por alguns antecedentes conhecidos, é de presumir que não deixa de exprimir-se segundo a linha de um calor optimismo histórico... (SARAMAGO, 2004, p.10)

Em essência, as posturas político-partidárias incidem um caráter hierárquico do pensamento e de fluências típicas que soam vozes impregnadas de discursos que se contradizem e se conflituam na tentativa de serem eleitos pela opinião pública. Pensar nesta esfera dialogante, implica ler o pensamento bakhtiniano (cf. Machado, 2001, p.265-266) como "um confronto de visões de mundo resultantes de diferentes posicionamentos". Nesse sentido, importa inferir o lugar de onde se diz e para quem se diz como delimitadores do que e do como se diz. No romance saramaguiano, esse confronto de visões aparece nas esferas discursivas em que cada unidade institui um nó potencializador de muitas questões, de muitos discursos.

A ênfase dada, no discurso do narrador, ao uso de letras iniciais em minúsculas para se referir aos nomes próprios, tais como as siglas (p.d.m., p.d.d. e p.d.e.) representando os partidos políticos e as correntes de pensamento político-partidário, nos faz ver que as mesmas potencializam um olhar crítico e irônico que põe, no mesmo nível, todas as instituições, inclusive deus, como mostramos anteriormente com a ilustração do discurso religioso. Isso traz a palavra, enquanto réplica do outro, às avessas, com acento deslocado e aleivosamente deformado (cf. Bakhtin, 1981).

Imbuído de uma implacável sutilidade, o narrador imprime ao funcionamento prático das ações que movimentam um país democrático regido por governantes, um estilo cômico e irônico que põe em cena uma visão crítica ao sistema que move o patrimônio de um país, de um povo: 
Acostumados à retórica do primeiro-ministro, do tipo três passos em frente, dois à retaguarda, ou, como mais popularmente se diz, do jeito de fazes-que-andas-mas-não-andas, os ministros aguardavam com paciência a última palavra, a derradeira, a final, aquela que daria explicação de tudo. (SARAMAGO, p.64)

A figurativização do discurso do primeiro-ministro, de um homem público, político e partidário, reflete e refrata uma visão de uma classe de governantes (federal, estadual e municipal) que, comumente, comporta um andar mais lento do que as promessas proclamadas nos discursos políticos-partidários. Em tom irônico, a voz do outro combate o discurso de que os governantes têm resposta para todas as inquietações que abalam o país e para enfrentar todos os problemas que conflituam o sistema democrático; o político-partidário deixa, assim, de ser um mito para os seus complacentes eleitores.

De um modo satírico, o estilo usado pelo narrador transparece um olhar sobre a sociedade que, conforme os princípios de Fiorin (2001, p.158), evidencia uma civilização que se institui por meio de vícios e vaidades:

Finalmente, expurgado dos elementos perturbadores, o conselho era um bloco coeso, um chefe, uma vontade, um projecto, um caminho. Sentado no cadeirão, como à dignidade do seu cargo competia, o presidente da república aplaudia com as pontas dos dedos, assim deixando perceber, também pela severa expressão de sua cara, a contrariedade que lhe causara não ter sido objecto de uma referência, sequer mínima, no discurso do primeiro-ministro. (SARAMAGO, p.176)

As formalidades repercutem uma voz que, burocratizada, ironiza as metas unificadoras do pensamento dos governantes e põe em conflito os paradigmas que resplandecem ora um espírito imbuído pela seriedade ora por uma demonstração medíocre que abala a estrutura aparentemente engajadora dos projetos de governo. As construções composicionais e estilísticas potencializam vozes que detalham toda a pompa que compete a um presidente da república, a um chefe de maior poder em uma determinada esfera hierárquica, de modo que o não dito instancia um embate de vozes: a responsabilidade que o cargo incute minimizada pelo formalismo e pela pomposidade.

Como uma incursão que dialoga com um senso de realidade, as vozes que emanam da voz do narrador proclamam ora um estereótipo de uma reação político-partidária frente a uma ameaça que venha a questionar o sistema que rege as ações de um país ora denúncias de falhas na execução do sistema, o que põe em jogo uma ameaça à aparente harmonia com a possibilidade de escândalos e manchas à imagem do governo e dos sujeitos neles envolvidos:

Nem ele acredita, pensou, a ele só lhe interessava um alvo qualquer a que apontar, se falhar este procurará outro, e outro, e outro, e tantos quantos forem necessários até acertar de vez, ou até que as pessoas a quem pretende convencer dos seus méritos acabem por se tornar, pela repetição, indiferentes aos métodos e processos usados. (SARAMAGO, p.254-255) 
Na voz do narrador, aparecem nuances de tons que embalam o discurso e tendem a harmonizar e/ou pôr em conflito as vozes, infringindo à totalidade enunciativa uma tessitura modelada em favor de um olhar crítico e realista por figurativizar o pensamento do homem no homem, do homem da idéia, do homem como reflexo de uma sociedade individualista despovoada de sentimentos. Isso ocorre por se ter em vista a preservação da integridade refletida numa constituição que, como um contradiscurso, valorizaria dizeres que exaltariam valores mais democráticos e justos do homem no homem.

O sistema democrático, enquanto uma bandeira de lutas, impregna os idealistas político-partidários de um discurso que tende a sublimar e a vangloriar o sistema e, nesta cortina de fumaça cega, o narrador saramaguiano, em palavras de Venturelli (2001, p.235), "termina por emprestar voz a tudo aquilo que ele pretendia erradicar da sociedade humana, ao não ouvir outras propostas que, quem sabe, colocassem em xeque os vorazes ídolos do sistema".

\section{Uma reflexão sobre o funcionamento polifônico da obra Ensaio sobre a Lucidez.}

De um modo significativo, observamos a instauração e o entrelaçamento de outras vozes que habitam a voz do narrador no romance em análise e, em essência, vimos emergir da linguagem saramaguiana os discursos social, religioso e político em um mundo ficcional, como uma manifestação artística que, diante das contribuições bakhtinianas, enunciam efeitos que insistem em dizer que o sentido da palavra sempre está além do dito. Observamos a prosa romanesca como um espaço propício à observação e ao instaciamento das reflexões teóricas que constituem nosso óculos de observação e que, em contato com os enunciados, potencializa um olhar revelador de um estilo permeado por muitas vozes que dialogam na obra Ensaio sobre a Lucidez.

Como uma instância dialógica, o tecido romanesco potencializa discursos mobilizados por um mundo em devir, onde tudo está em movimento e nada está terminado, nem mesmo "a última palavra do mundo e sobre o mundo foi pronunciada" (Bakhtin apud Machado, 2001, p.242). Como uma esfera que permeia o todo discursivo, a voz social potencializa dizeres regidos por uma tradição popular e cultuados pela coletividade, por sujeitos que participam da linguagem enquanto indivíduos socialmente constituídos. A demonstração dos anseios perpassa o social como um fio condutor que eleva o dizer às esferas religiosa e política.

Os efeitos de sentido polifônico protagonizam um já-dito, evidenciado pela heterogeneidade de vozes mescladas à do narrador, que, através de sátiras e ironias, aponta as 
contradições presentes nas diferentes esferas de atividade humana. Imanentes do social, o discurso político-partidário possui sua força atenuada e revigorada pelo discurso religioso que impõe a crença e a fé como essências inspiradoras de um ser glorificado e puro e que se constituiria num Deus para muitos cegos, ainda contaminados pela cegueira branca e num deus para muitos que deixaram o branco revelar à visão um olhar observador, puro, realista e lúcido.

A esse respeito, Saramago, em epígrafe, resplandece um ar de protesto: "Uivemos, disse o cão". O coro das vozes que rege o romance saramaguiano ecoa, conforme diria Machado (2001, p.246), até mesmo numa leitura silenciosa. O estilo composicional do escritor português eleva a "ficcionalidade [...] não apenas da linguagem, mas também dos homens e de suas ações que se articulam enquanto matéria narrada" (Machado, 2001, p.261). As vozes se entrelaçam numa estrutura de enunciados encadeados livremente, numa transgressão da pontuação convencional que aponta para a oralidade e que mobiliza, segundo Peiruque (1994, p.569), “discursos potencializadores de um jeito que as palavras têm de puxar umas pelas outras". Com um estilo dinâmico, livre e pessoal, o narrador anuncia uma ruptura com os padrões da estrutura formal romanesca do século XIX.

Em conformidade com os estudos de Roani (2001, p.232), a multiplicidade de vozes é emergente do diálogo com o outro, refletindo a intencionalidade dos discursos em graus diferenciados de crítica e de polêmica. A concepção de um narrador, visto como regente e harmonizador de um incessante concerto de vozes, encontra respaldo, nos dizeres de Saramago (apud Roani, 2001, p.232): "pelo caráter polifônico que o narrador assume na minha ficção, porque realmente eu não me vejo a usar um narrador que seja ele próprio unilinear, que conte e que narre unilinearmente aquilo que, digamos, tem a dizer".

A malha discursiva prescinde, em palavras de Bakhtin (apud Machado, 2001, p.258), "as linguagens do plurilingüismo, como espelhos que apontam um para o outro, cada um dos quais refletido a seu modo um [...] cantinho do mundo, forçam a adivinhar e captar atrás dos seus aspectos mutuamente refletidos um mundo mais amplo..." Nesse sentido, os princípios bakhtinianos instauram, a nosso ver, um olhar potencial para a percepção da relação entre polifonia e discurso literário. Evidenciamos com este estudo tal relação pela ilustração de um embate de vozes social, religiosa e política presente na voz do narrador da obra Ensaio sobre a Lucidez de José Saramago. 


\section{Conclusão}

Esse estudo pretendeu responder às seguintes questões: 1) Como se instaura a polifonia na voz do narrador na obra Ensaio sobre a Lucidez, de José Saramago? 2) Como se produzem os efeitos de sentido na voz do narrador da obra em estudo para instaurar o outro? Para respondê-las, buscamos, nos princípios teóricos de Bakhtin, instrumentos para analisar a criação artístico-literária de Saramago, através da verificação, na voz do narrador da obra Ensaio sobre a Lucidez, das projeções de outras vozes.

Observamos o gênero romanesco povoado por discursos que representam e enquadram a voz de outrem, por um autor que, nos dizeres de Bakhtin (1990, p.156), "cria uma perspectiva para ele, distribui suas sombras e suas luzes, cria uma situação e todas as condições para sua ressonância, enfim, penetra nele de dentro, introduz nele seus acentos e suas expressões, cria para ele um fundo dialógico".

Os discursos se instauram no romance revestidos por efeitos de sentido polifônicos que resplandecem "uma imagem viva de uma outra linguagem" (Bakhtin, 1990, p.159), uma imagem que, refletida e refratada no social, constitui-se num dizer que se instancia numa esfera de representação e recupera a intensidade de um dito, de uma voz quer social, quer religiosa, quer política. Deste modo, inspiradas por Bakhtin (1990, p.87), pensamos no sistema democrático, temática central do romance, como um ícone que se faz cercar por uma atmosfera social e que o toma como objeto para potencializar outros discursos.

Em seu todo, através de um jogo polifônico, a prosa romanesca de Saramago potencializa dizeres emergentes de uma visão inacabada de mundo, de uma reflexão imbuída de uma sutilidade satírica, irônica e questionadora sobre o homem no mundo, sobre "a sua aparência e o seu fundo, entre as possibilidades e a sua realização" (Bakhtin, 1990, p.424). A oscilação entre a sobrevivência de um olhar tumultuado, ainda pela cegueira branca, e a instauração de um olhar inquieto, questionador e lúcido mobilizado pelo voto em branco, reflete uma esfera inspiradora de vozes que se enfrentam, se contradizem e se harmonizam em prol de uma luta, de um porvir que, em palavras de Bakhtin (1990, p.425), "não pode deixar de se referir à imagem do homem, de ter suas raízes nele".

Com um estilo revestido de sutilidade, o narrador orquestra, em sua voz, discursos oriundos das esferas social, religiosa e política que dizem do sistema democrático e que potencializam, na atmosfera romanesca, ares inquietantes e contraditórios de uma pluridiscursividade que se circunscreve em torno da temática. Nesse sentido, enfatizamos um 
olhar instanciado pelas construções polifônicas do narrador no romance em estudo, já que conforme os estudos bakhtininos:

O prosador não purifica seus discursos das intenções e tons de outrem, não destrói os germes do plurilingüismo social que estão encerrados neles, não elimina aquelas figuras lingüísticas e aquelas maneiras de falar, aqueles personagens-narradores virtuais que transparecem por trás das palavras e formas da linguagem, porém, dispõe todos estes discursos e formas a diferentes distâncias do núcleo semântico decisivo da sua obra, do centro de suas intenções pessoais. (BAKHTIN, 1990, p. 104-105)

Procuramos, assim, fazer dialogar os princípios bakhtinianos com a produção literária de Saramago, com o propósito de observar, na voz do narrador da obra Ensaio sobre a Lucidez, o ressoar de outras vozes, instanciadas, neste estudo, pela evidência de um cohabitar, no discurso do narrador, de outros discursos, que nomeamos aqui como social, religioso e político-partidário.

\section{Referências}

BAKHTIN, Mikhail. Questões de literatura e de estética: a teoria do romance. 2.ed. São Paulo: Unesp; Hucitec, 1990.

. Estética da criação verbal. 4.ed. São Paulo: Martins Fontes, 2000.

. Marxismo e filosofia da linguagem. 3. ed. São Paulo: Hucitec, 1986.

. Problemas da poética de Dostoiévski. Rio de Janeiro: Forense Universitária, 1981.

BARROS, Diana Luz Pessoa de. Dialogismo, polifonia e enunciação. In: BARROS, Diana Luz Pessoa de; FIORIN, José Luiz (Orgs.). Dialogismo, polifonia, intertextualidade. 2. ed. São Paulo: Ed. da Edusp, 2003.

BERNARDI, Rosse-Marye. Uma leitura bakhtiniana de Vastas emoções e pensamentos imperfeitos, de Rubem Fonseca. In: FARACO, Carlos Alberto; CASTRO, Gilberto de (Orgs.) et al. Diálogos com Bakhtin. 3. ed. Curitiba: Ed. da UFPR, 2001.

BEZERRA, Paulo. Polifonia. In: BRAIT, Beth (Org.). Bakhtin: conceitos-chave. São Paulo: Contexto, 2005, p. $191-200$.

FIORIN, José Luiz. O romance e a representação da heterogeneidade constitutiva. In: FARACO, Carlos Alberto; CASTRO, Gilberto de (Orgs.) et al. Diálogos com Bakhtin. 3. ed. Curitiba: Ed. da UFPR, 2001.

LOPES, Edward. Discurso literário e dialogismo em Bakhtin. In: BARROS, Diana Luz Pessoa de; FIORIN, José Luiz (Orgs.). Dialogismo, polifonia, intertextualidade. 2. ed. São Paulo: Ed. da EDUSP, 2003, p. 63 - 81. 
MACHADO, Irene A. Os gêneros e a ciência dialógica do texto. In: FARACO, Carlos Alberto; CASTRO, Gilberto de (Orgs.) et al.. Diálogos com Bakhtin. $3^{\mathrm{a}}$. ed. Curitiba: Ed. da UFPR, 2001.

PEIRUQUE, Elisabete. Saramago: o fascínio da linguagem, um discurso fascinante. In: Anais do XIV Encontro de professores universitários brasileiros de literatura portuguesa Literaturas de língua portuguesa e a renovação do discurso literário. Porto Alegre: EDIPUCRS, 1994.

ROANI, Gerson Luiz. A história comanda o espetáculo do mundo: ficção, história e intertexto em O ano da morte de Ricardo Reis de José Saramago. 2002. 378fs. Tese (Doutorado em Literatura Comparada) - Universidade Federal do Rio Grande do Sul - UFRGS, Porto Alegre, 2002.

SARAMAGO, José. Ensaio sobre a cegueira. São Paulo: Companhia das Letras, 1995.

. Ensaio sobre a lucidez. São Paulo: Companhia das Letras, 2004.

. Memorial do Convento. São Paulo: Ed. Bertrand Brasil, 1982.

. O evangelho segundo Jesus Cristo. São Paulo: Companhia das Letras, 1991.

SILVA, Carmem Luci da Costa e. A polifonia no discurso narrativo infantil. Porto Alegre: Ed. da UFRGS, 1996. Dissertação (Mestrado em Letras) - Universidade Federal do Rio Grande do Sul - UFRGS, Porto Alegre, 1996.

VENTURELLI, Paulo. Deus e o diabo no corpo dos meninos - sexualidade, ideologia e literatura: diálogos. In: FARACO, Carlos Alberto; CASTRO, Gilberto de (Orgs.) et al.. Diálogos com Bakhtin. $3^{\text {a }}$. ed. Curitiba: Ed. da UFPR, 2001. 